\title{
Rancang Bangun WSN berbasis nRF24L01 dan SIM8001 bertenaga Surya untuk Implementasi IoT secara Outdoor
}

\author{
Wirarama Wedashwara ${ }^{*}$, Budi Irmawati ${ }^{2}$, Andy Hidayat Jatmika ${ }^{3}$, Ariyan Zubaidi ${ }^{4}$ \\ 1,2,3,4 Program Studi Teknik Informatika, Universitas Mataram \\ email:wirarama@unram.ac.id*1, budi-i@unram.ac.id², andy@unram.ac.id ${ }^{3}$, \\ zubaidi13@unram.ac.id ${ }^{4}$
}

(Received: 28 Oktober 2021 / Accepted: 21 November 2021 / Published Online: 20 Desember 2021)

\begin{abstract}
Abstrak
Internet of things (IoT) membutuhkan jaringan internet dalam komunikasi data antar mesin. Wifi tidak selalu tersedia pada luar ruangan dan memerlukan komunikasi data yang lebih portable. Penelitian ini bertujuan untuk merancang bangun prototype Wireless Sensor Network (WSN) berbasis nRF24L01 dan SIM8001 bertenaga surya untuk Implementasi IoT secara outdoor. Penelitian ini menggunakan total lima perangkat IoT dengan empat nodes dengan nRF24L01 dan satu node dengan nRF24L01 dan SIM8001. Setiap perangkat menggunakan arduino nano, TP4056, 6WP solar panel dan baterai $900 \mathrm{mAh} 18650$. Evaluasi sistem mencakup analisis komparatif $Q o S$ yaitu packet delivery ratio $(P D R)$, throughput dan delay pada topology star dan bus melalui pengumpulan data metode observasi oleh sensor. Hasil evaluasi menunjukkan untuk komunikasi data searah topology star memiliki hasil yang lebih baik dengan PDR 99,099\%, throughput 99,393\% dan delay 0,0095s. Sedangkan topologi bus menghasilkan perbedaan tipis PDR 98,766\%, throughput $98,461 \%$ dan delay $0,017 \mathrm{~s}$. Evaluasi ketersediaan energi menunjukkan waktu siang hari dengan rata-rata tegangan 3,703v dan malam hari 2,976v tidak menghasilkan perbedaan yang signifikan. Siang hari menghasilkan PDR $99.301 \%$, throughput $99,653 \%$ dan delay 0,001 s, sedangkan malam hari PDR $94,221 \%$, throughput $99,881 \%$ dan delay $0,027 \mathrm{~s}$.
\end{abstract}

Kata kunci: Internet of Things, nRF24L01, Tenaga Surya, Wireless Sensor Network

\begin{abstract}
Internet of things (IoT) requires an internet network for data communication between machines. Wifi is not always available outdoors and requires more portable data communication. This study aims to design a prototype Wireless Sensor Network (WSN) based on nRF24L01 and solar-powered SIM800l for outdoor IoT implementation. The study used a total of five IoT devices with four nodes with nRF24L01 and one node with nRF24L01 and SIM800l. Each device uses an Arduino nano, TP4056, 6WP solar panel, and a $900 \mathrm{mAh} 18650$ battery. The evaluation of the system includes a comparative QoS analysis, namely packet delivery ratio (PDR), throughput, and delay in star and bus topology through data collection of observation methods by sensors. The evaluation results show that for unidirectional data communication the star topology has better results with PDR 99,099\%, throughput $99.393 \%$, and delay 0.0095s. While the bus topology produces a slight difference in PDR $98.766 \%$, throughput $98.461 \%$, and delay 0.017 s. Evaluation of energy availability shows that during the day with an average voltage of $3.703 \mathrm{v}$ and at night $2.976 \mathrm{v}$, there is no significant difference. During the day it produces $99.301 \%$ PDR, 99.653\% throughput, and 0.001s delay, while at night it produces $94.221 \%$ PDR, $99.881 \%$ throughput, and 0.027 s delay.
\end{abstract}

Keywords: Internet of Things, Wireless Sensor Network, nRF24L01, Solar Power 


\section{PENDAHULUAN}

Internet of Thing adalah sistem yang menggabungkan embedded system, sistem informasi dan komunikasi data melalui internet tanpa interaksi yang melibatkan manusia secara langsung(Li et al., 2018). Implementasi Internet of Things (IoT) pada outdoor tidak selalu dilakukan pada lingkungan dengan ketersiadaan internet berupa wifi yang lebih mudah dikendalikan melalui DHCP (Bassoli et al., 2017). NRF24L01 transreceiver memungkinkan komunikasi data untuk wireless sensor network (WSN) dengan biaya yang murah dan jangkauan hingga $1 \mathrm{~km}$ (Gao et al., 2021). GPRS module tetap diperlukan untuk mengumpulkan data dari masing-masing IoT nodes dan menguploadnya ke internet sehingga data dapat dimonitoring melalui internet (Lauridsen et al., 2017). Sumber listrik tenaga surya digunakan untuk membuat sistem sepenuhnya wireless, sehingga masing-masing nodes bisa ditempatkan dengan lebih bebas (Yoon et al., 2017).

Permasalahan yang muncul adalah belum adanya penelitian tentang pengaruh ketersediaan energi terhadap QoS pada WSN yang diterapkan diluar ruangan. Sebagai solusi permasalahan tersebut penelitian bertujuan untuk merancang bangun prototype Wireless Sensor Network (WSN) berbasis nRF24L01 dan SIM8001 bertenaga surya untuk Implementasi IoT secara outdoor. Tujuan penelitian adalah menghasilkan sistem WSN baru yang sepenuhnya portable dapat melakukan monitoring Quality of Service (QoS) sekaligus ketersediaan tenaga surya. Penelitian menggunakan total lima perangkat IoT dengan empat nodes dengan nRF24L01 dan satu node dengan nRF24L01 dan SIM8001. Masing-masing perangkat menggunakan satu arduino nano, TP4056, 6WP solar panel dan 900mAh 18650 battery. Khusus untuk perangkat dengan SIM8001 menggunakan dua solar panel dan baterai karena module dan stepdown module SIM8001 memerlukan tegangan konstan $4.2 \mathrm{v}$. Penelitian ini dilakukan berdasarkan penelitian sebelum mengenai evaluasi IoT bertenaga surya namun menggunakan komunikasi data wifi (Wedashwara et al., 2020).

Topologi jaringan star dan bus akan diujikan pada penelitian. Pada topologi jaringan bus, node terjauh akan mengirimkan data sensornya ke perangkat terdekatnya hingga menuju node dengan SIM8001 (Vaidya et al., 2017). Sehingga paket data bertambah panjang berupa array character hingga diupload sekalian. Pada topologi star data direkap dari masing-masing node secara langsung dan diupload sekalian ketika semua data terkumpul (Keliwar, 2020). Kelemahan topologi star adalah semua nodes harus berada dalam jangkauan. Sedangkan topologi bus memungkinkan jangkauan yang lebih luas jika masing-masing nodes masih terhubung dalam jangkauan dengan nodes lainnya. Kedua topologi akan diujikan pada penempatan nodes yang sama yaitu semua nodes berada dalam jangkauan $1 \mathrm{~km}$. Kondisi ini tentunya akan menguntungkan topologi star, namun penelitian ini dilakukan untuk mengetahui selisih antar topologi.

Penelitian IoT dengan jaringan Wifi sudah banyak dilakukan seperti pada (Akbar \& Gunawan, 2020). Penelitian tentang penggunakan nRF24L01 sudah dilakukan oleh beberapa peneliti untuk implementasi pada ICG monitoring system (Aponte-Luis et al., 2018), glucose monitoring system (Iwasaki et al., 2014), crowd management system for public transport (Vidyasagaran et al., 2017), hingga autonomous farming robot (Khan et al., 2020). Penelitian tersebut berfokus pada implementasi dan tidak membahas sumber kelistrikan secara khusus. Penelitian yang diusulkan berfokus pada kualitas komunikasi data dengan mempertimbangkan ketersediaan listrik melalui tenaga surya.

Sistem monitoring menggunakan IoT telah dilakukan untuk monitoring solar power generator (Lee et al., 2017). Penelitian berfokus pada monitoring kinerja generator tenaga surya dan tidak menggunakan nRF24L01. Implementasi nRF24L01 dan tenaga surya untuk sistem irigasi cerdas sudah dilakukan (Abayomi-Alli et al., 2018). Penelitian ini berfokus pada implementasi sistem dan tidak berfokus pada kualitas komunikasi data. Penelitian tersebut juga tidak menggunakan rekap data menggunakan SIM8001. 
Selanjutnya, penelitian ini menggunakan SIM8001 dan nRF24L01 sebagai komunikasi data telah dilakukan untuk implementasi monitoring (Wang et al., 2019) dan controlling saline level with health constants dan automated sewerage management (Talukder et al., 2017). Kedua penelitian tersebut tidak menggunakan tenaga surya dan tidak membahas kelistrikan secara khusus. Selain itu, penelitian ini bertujuan untuk merancang bangun sistem monitoring tenaga surya dan QoS serta melakukan evaluasi hubungan antar tenaga surya dan QoS. Sejauh yang kami telusuri belum ada penelitian yang melakukan pengembangan sistem maupun evaluasi tersebut.

\section{METODE}

Penelitian ini dilakukan pada Laboratorium Komunikasi Data dan Sistem Tertanam, Program Studi Teknik Informatika, Fakultas Teknik, Universitas Mataram. Kegiatan pengembangan prototype dilakukan mulai 4 hingga 7 oktober 2021. Pengembangan prototype mencakup pengembangan perangkat elektronik IoT, pemrograman microcontroller dan server-side yang akan menyimpan data. Pengujian dilakukan selama dua hari yaitu 8 dan 9 oktober 2021. Pengumpulan data dilakukan dengan metode observasi yang dilakukan oleh sensor yang terpasang pada perangkat IoT.

Evaluasi sistem mencakup pengujian perbandingan quality of services (QoS) data yaitu packet delivery ratio (PDR), throughput dan delay pada topology star dan bus (Lee \& Ke, 2018). Selain itu evaluasi juga membandingkan kualitas komunikasi data dengan ketersediaan energi yang diukur melalui voltage dari baterai.

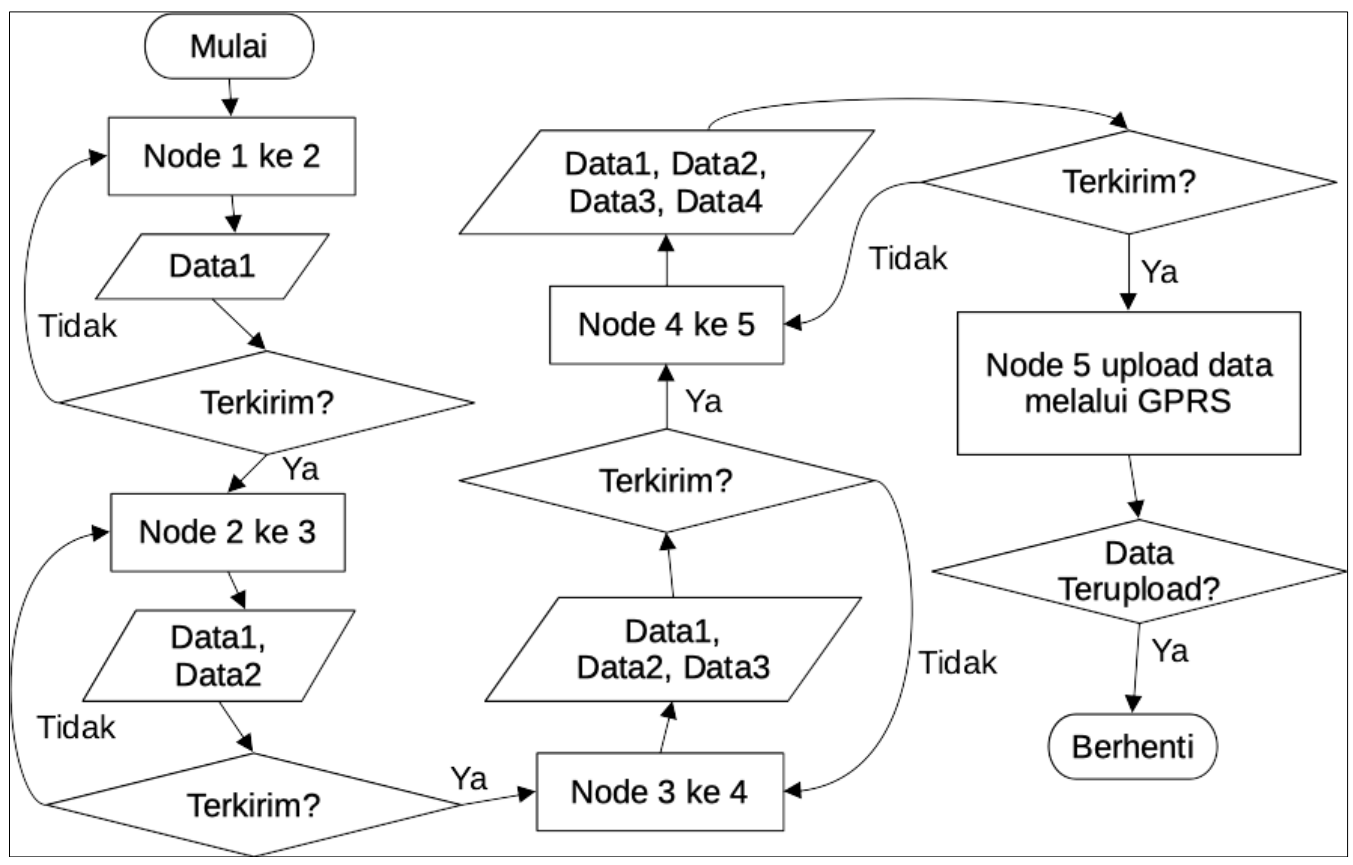

Gambar 1. Flowchart Topologi Bus

Gambar 1 menunjukkan flowchart dari topologi bus yang akan diterapkan pada jaringan nRF24L01 dan SIM8001. Transmisi data berlangsung dari node 1 ke 2, node 2 ke 3, node 3 ke 4 dan akhirnya dari node 4 ke 5 . Data diteruskan hingga node 5 secara incremental dalam format digit sesuai value sensor tanpa tanda pemisah. Node 5 yang berisi module SIM8001 akan mengupload data ke internet sekaligus melalui HTTP GET sehingga efisien dalam penggunaan akses. Setiap transmisi data tidak akan lanjut ke proses transmisi berikutnya. Sehingga keterlambatan data dapat terjadi ketika ada node yang gagal mengirim ke node berikutnya. 


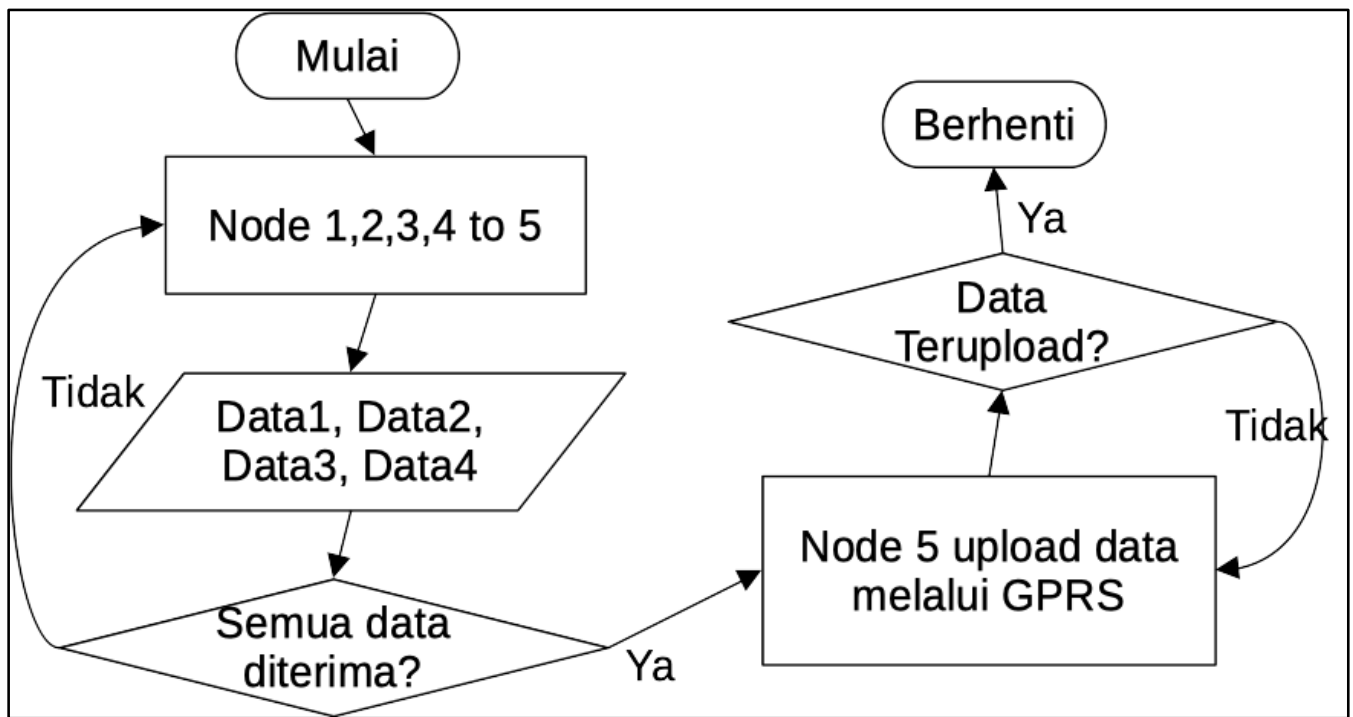

Gambar 2. Flowchart Topologi Star

Gambar 2 menunjukkan flowchart untuk topologi star yang akan diterapkan pada jaringan nRF24L01 dan SIM8001. Node 1, 2, 3, 4 mengirimkan data secara bersamaan kepada node 5. Walaupun secara bersamaan, setiap sensor yang terpasang pada setiap node memiliki refresh rate yang berbeda sehingga tidak bisa diterima secara bersamaan. Node 5 diprogram untuk menerima data mulai dari node dengan refresh rate terendah hingga tertinggi. Data tidak akan diupload hingga semua data dari setiap node sudah diterima oleh node 5. Sehingga keterlambatan upload masih bisa terjadi jika ada node yang mengalami kegagalan pengiriman data.

Topologi star tampak lebih sederhana dari segi komunikasi data. Pada penerapan pemrograman pada perangkat nRF24L01 receiver memiliki kerumitan karena tidak dapat menerima data sekaligus dari semua node tetapi harus bergantian. Sehingga diperlukan pengetahuan dalam refresh rate setiap sensor untuk efisiensi penerimaan data. Topologi star juga memiliki kekurangan semua node harus tidak jauh dari $1 \mathrm{~km}$ dari node 5 . Sedangkan topologi bus memungkinkan komunikasi data dengan jangkauan lebih luas yaitu jumlah node dikali jangkauan $1 \mathrm{~km}$.

\section{HASIL DAN PEMBAHASAN}

\section{Hasil}

Hasil temuan kami mencakup developed IoT system dalam schema dan realisasi pada PCB dan refresh rate sensor yang terhubung pada masing-masing IoT nodes. Temuan yang diusulkan pada penelitian ini adalah sistem WSN yang dapat bekerja dengan jaringan nRF24101 dan tenaga surya untuk aplikasi outdoor tanpa akses wifi.

\section{Rangkaian IoT}

Gambar 3 menunjukkan rangkaian pada IoT node 1 hingga 4. Gambar 3 menunjukkan keempat (dht11, LDR, soil humidity dan water level) sensor terhubung pada satu arduino nano tetapi pada prakteknya masing-masing sensor terhubung pada arduino nano yang berbeda yaitu node 1 hingga 4 . Node 1 hingga 4 terhubung dengan module nRF24L01 dengan 7 pin yang terhubung pada vcc 3.3v, gnd dan 5 digital pin. Setiap sensor memiliki tegangan input $5 \mathrm{v}$ dan terhubung pada input analog, kecuali dht11 yang terhubung dengan input digital. Sensor analog dipilih karena tidak tergantung pada library dalam pemrograman. 


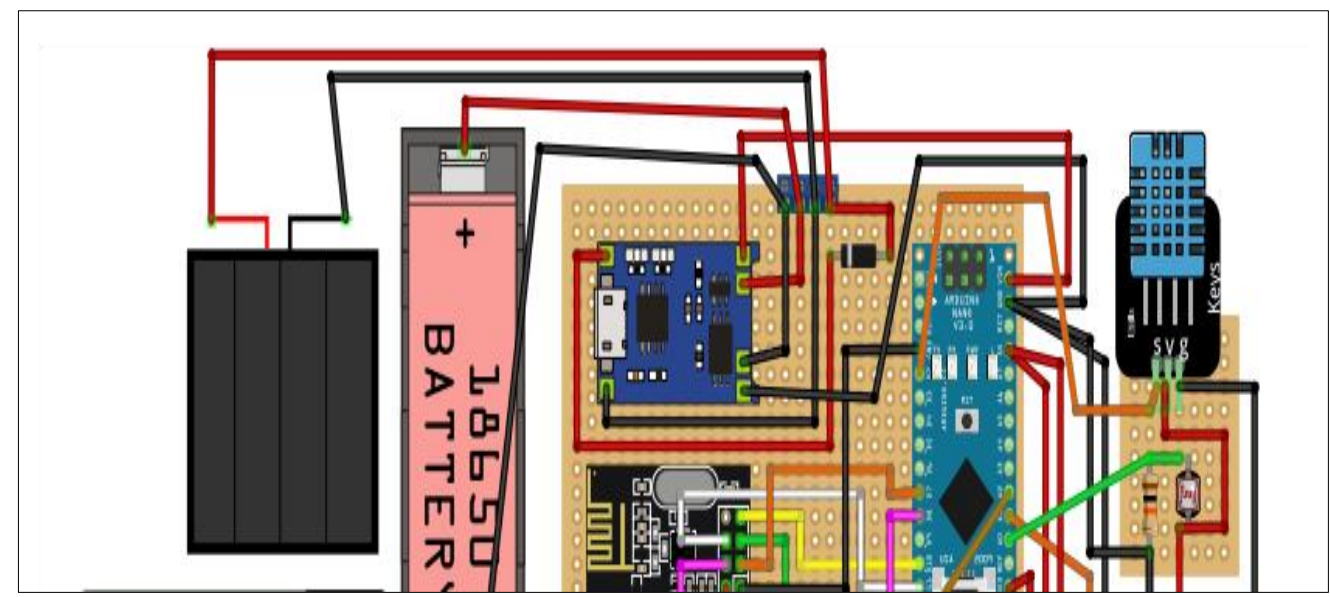

Gambar 3 Rangkaian Sistem IoT untuk Node 1 Hingga 4

Gambar 4 menunjukkan rangkaian pada node 5 yang selain terhubung dengan nRF24L01 sebagai receiver, juga terhubung dengan SIM8001 yang akan mengupload data node 1 hingga 4 ke internet. SIM8001 menggunakan tegangan $4.2 \mathrm{v}$ sehingga tidak cukup dengan baterai 3.7v. XL6009 step up module digunakan untuk menaikkan tegangan dari dua baterai $3.7 \mathrm{v}$ yang dirangkai paralel sehingga kapasitas menjadi dua kali lipat. Sistem menggunakan dua baterai untuk mengurangi beban dari XL6009 ketika kapasitas menurun. Sebagai alternatif bisa juga digunakan step down module dengan rangkaian baterai seri tetapi hal tersebut akan memerlukan dua buah charging module.

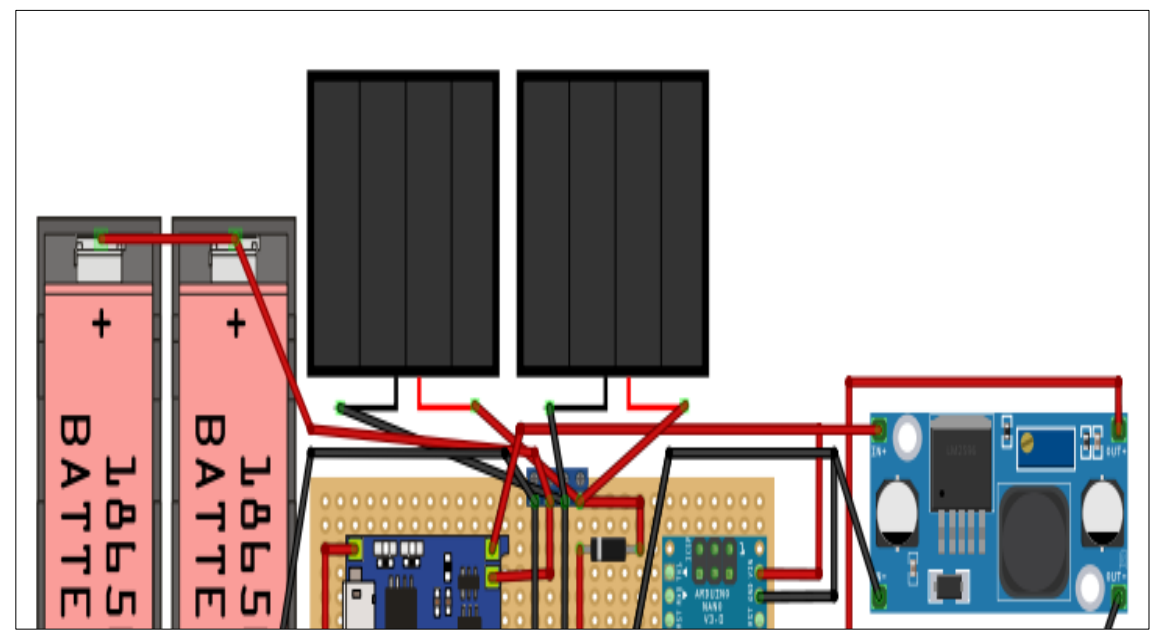

Gambar 4 Rangkaian Sistem IoT untuk Node 5

Node 1 hingga 4 menggunakan TP4056 sebagai charging module melalui solar panel 6WP. TP4056 juga memiliki battery protection untuk membatasi tegangan baterai agar tidak over charging dan tidak mensupply energy ketika tegangan terlalu rendah karena penurunan kapasitas. Hal ini bertujuan memberikan kestabilan komunikasi data dan nRF24L01 dan SIM8001.

Pada gambar 5, bagian (a) menunjukkan node 5 dengan nRF24L01 dan SIM8001 yang terhubung dengan TP4056, XL6009, dua pasang baterai 18650 dan solar cell dalam satu kotak. Bagian (b) menunjukkan node 3 dan 2 yang terhubung dengan TP4056, baterai 18650 dan solar cell pada masing- masing kotak. Node 3 terhubung dengan LDR sensor dan node 2 terhubung dengan water level sensor. Bagian (c) menunjukkan node 4 dan 1 yang terhubung dengan TP4056, baterai 18650 dan solar cell pada masing- masing kotak. Node 4 terhubung dengan DHT11 dan node 1 terhubung dengan water level sensor. 


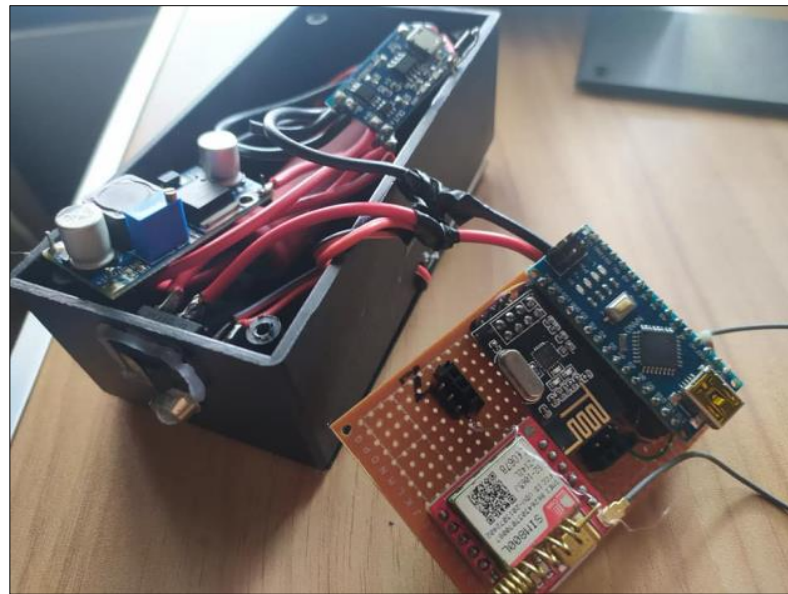

(a) Node 5

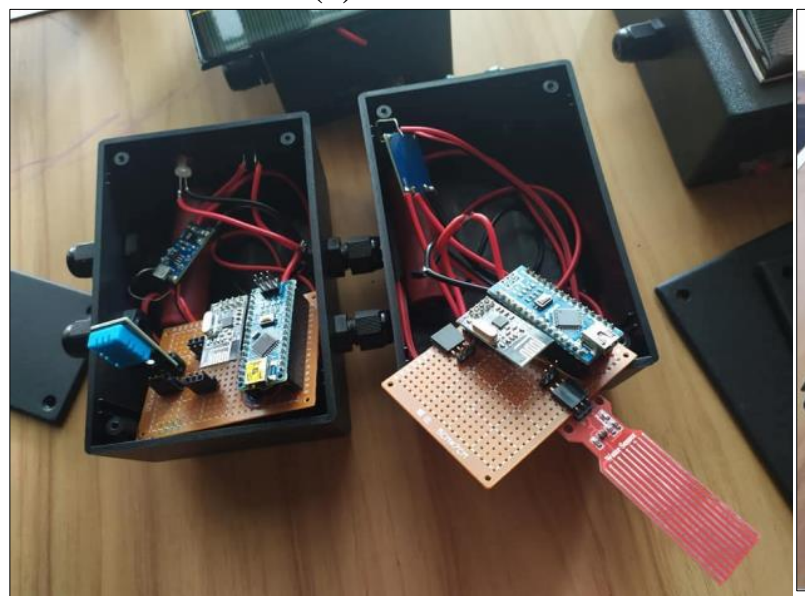

(c) Node 4 dan 1

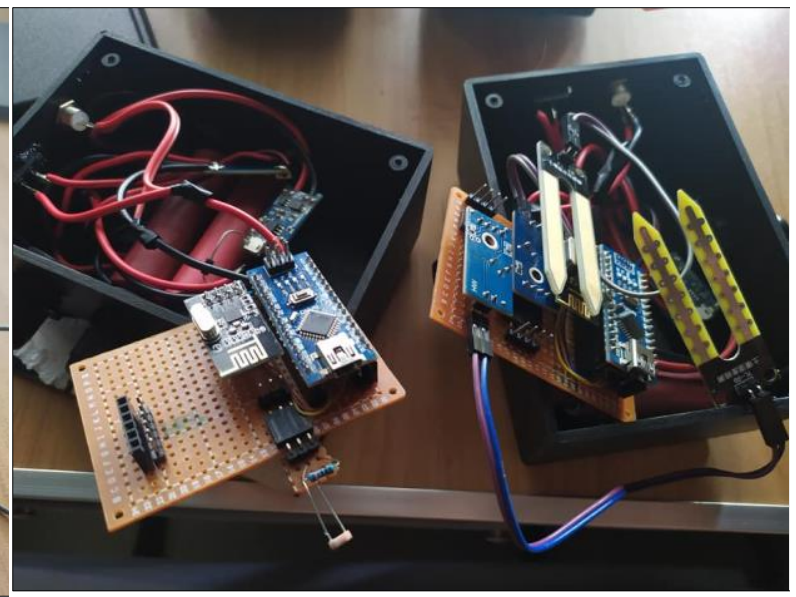

(b) Node 3 dan 2

Gambar 5. Tampilan Nyata Sistem IoT

Bagian (d) menunjukkan solar cell di atas kotak kelima nodes. Masing-masing memiliki satu buat solar cell kecuali node 5 yang memiliki 2 solar cells. Setiap kotak juga dilengkapi dengan lampu LED dan saklar sebagai indikasi node sedang aktif. Kemasan ini membuat masing-masing node sepenuhnya portable untuk diletakkan dimana saja selama ada sumber cahaya matahari.

Setiap node dibuat dalam PCB single layer $5 \times 7 \mathrm{~cm}$. Rangkaian listrik dirangkai menggunakan wire wrapping dengan menggunakan pin header female dan male yang di padding melalui solder. Sehingga kualitas kabel lebih baik karena tidak pernah terkena panas solder dan lebih solid karena dililit dengan alat khusus. Hanya kabel solar cell, baterai, led dan saklar yang di solder karena menggunakan kabel yang lebih tebal dan tahan panas.

\section{Refresh Rate dan Sinkronisasi Pengiriman Data}

Tabel 1 menunjukkan sensor yang terpasang pada setiap node, refresh rate dalam milli second, jumlah characters dan packet size dalam byte. Water level sensor pada node 1 hanya berisi data boolean sehingga hanya menghabiskan 1 byte dan memiliki refresh rate terendah yaitu 500ms. Node 2 dengan soil moisture sensor memiliki rate antara 0 hingga 100\% sehingga menggunakan 3 bytes dan memiliki refresh rate $1000 \mathrm{~ms}$. Light dependent resistor (LDR) pada node 3 memiliki value dari 100 hingga 100M Ohm sehingga menghabiskan 9 bytes. Node 4 dengan DHT11 memiliki dua output yatu suhu dan kelembaban udara sehingga digabung menggunakan 8 bytes dan memiliki refresh rate teritinggi yaitu 2000ms. 
Tabel 1. Refesh Rate dan Packet Size dari Masing-Masing Node

\begin{tabular}{ccccc}
\hline Node & Sensor & $\begin{array}{c}\text { Refresh Rate } \\
(\mathbf{m s})\end{array}$ & Karakter & $\begin{array}{c}\text { Packet Size } \\
\text { (byte) }\end{array}$ \\
\hline $\mathbf{1}$ & Water Level (Boolean) & 200 & $0 \sim 1$ & 1 \\
$\mathbf{2}$ & Soil Moisture (\%) & 500 & $000 \sim 100$ & 3 \\
$\mathbf{3}$ & LDR (Ohm) & 500 & $000000100 \sim 100000000$ & 9 \\
$\mathbf{4}$ & DHT11 (oC and \%) & 1000 & $00.00000 \sim 50.00100$ & 8 \\
& & 2200 & 100100000010030.01050 & 21 \\
\hline
\end{tabular}

Tabel 1 menunjukkan gabungan karakter menghasilkan 21 bytes tanpa tanda pemisah. Pada pemrograman di sisi server data dipisahkan berdasarkan index array pada string sesuai jumlah characters masing-masing sensor. Maksimal paket yang bisa dikirim oleh nRF24L01 adalah 32 bytes sehingga jika dihitung persentase 21/32 hanya menggunakan $65,625 \%$ dari total bandwidth. Throughput dihitung dengan maksimal 21 byte data. Packet loss akan dihitung untuk perbandingan keberhasilan dan kegagalan setiap node dalam mengirimkan data. Sedangkan delay dihitung berdasarkan selisih dengan refresh rate dari total sensor yaitu $2200 \mathrm{~ms}$ sesuai total pada tabel 1 .

\section{Pembahasan}

Pembahasan mencakup: perbandingan kualitas komunikasi data pada topologi bus dan star dan terakhir adalah evaluasi ketersediaan energi dalam sistem. Pada hipotesis diharapkan sistem memiliki QoS yang baik dan memiliki ketersediaan energi untuk beroperasi selama 24 jam penuh.

Perbandingan Quality of Service (QoS) dari Topologi Star dan Bus

Tabel 2 menunjukkan QoS dari topologi star pada jaringan nRF24L01 pada setiap nodes. Topologi star memiliki rata-rata throughput $99,393 \%$ dengan nlai terendah pada node 4 yang berisi DHT11 dengan 97,887\%. Rata-rata PDR adalah 99.099\% dan node 4 terendah pada $97,254 \%$. Rata rata delay adalah 0.0095 s dan node 4 tetap terlambat dengan $0,016 \mathrm{~s}$. DHT11 merupakan sensor digital yang cukup sensitif terhadap kestabilan listrik sehingga lebih rentan dibanding sensor yang lain. Namun QoS dari node 4 tetap masih tinggi yaitu throughput 97,887, PDR 97,254 dan delay hanya 0,016 seperti ditunjukkan pada tabel 2.

Tabel 2. QoS dari Topologi Star

\begin{tabular}{cccc}
\hline Node & Throughput $(\boldsymbol{\%})$ & PDR $(\boldsymbol{\%})$ & Delay $(\mathbf{m s})$ \\
\hline $\mathbf{1}$ & 99,898 & 99,938 & 0,004 \\
$\mathbf{2}$ & 99,895 & 99,932 & 0,007 \\
$\mathbf{3}$ & 99,893 & 99,273 & 0,011 \\
$\mathbf{4}$ & 97,887 & 97,254 & 0,016 \\
Rata-rata & 99,393 & 99,099 & 0,0095 \\
\hline
\end{tabular}

Tabel 3 menunjukkan QoS dari topologi bus pada jaringan nRF24L01 pada setiap nodes. Topologi bus memiliki throughput $98,461 \%$ dengan node 4 terendah pada $96,002 \%$. Rata-rata PDR adalah 98,766\% dengan node 4 terendah pada 97,021\%. Rata-rata delay adalah 0,017 dengan node 4 tetap terendah pada 0,024. Setiap parameter QoS pada topologi bus lebih buruk dari topologi star dengan selisih thoughput 0,932\%, PDR 0,334\% dan delay 
0,007s. Tampak topologi star lebih baik tetapi selisih ini sangat sedikit untuk sifat topologi bus yang lebih menguntungkan dari distribusi lokasi sensor.

Tabel 3 QoS dari Topologi Bus

\begin{tabular}{cccc}
\hline Node & Throughput $(\boldsymbol{\%})$ & PDR $(\boldsymbol{\%})$ & Delay $(\mathbf{m s})$ \\
\hline $\mathbf{1}$ & 99,845 & 99,876 & 0,006 \\
$\mathbf{2}$ & 99,836 & 98,987 & 0,018 \\
$\mathbf{3}$ & 98,162 & 99,178 & 0,019 \\
$\mathbf{4}$ & 96,002 & 97,021 & 0,024 \\
Rata-rata & 98,461 & 98,766 & 0,017 \\
\hline
\end{tabular}

\section{Evaluasi Ketersediaan Tenaga Surya}

Tabel 4 menunjukkan evaluasi tenaga surya yang dihasilkan oleh solar cell dan baterai dan perbandingannya dengan light intensity dan ambient temperature serta QoS yaitu throughput, PDR dan delay. Data dibagi berdasarkan perbedaan waktu berdasarkan suhu dan intensitas cahaya menjadi 8 cluster yaitu 08-11, 11-16, 16-18, 18-20, 05-18. Clustering dilakukan menggunakan genetic network programming (GNP) rule based clustering yang telah dikembangkan sebelumnya (Wedashwara et al., 2015). Pengukuran energi yang dihasilkan oleh solar cell dan baterai diukur menggunakan perangkat yang telah dikembangkan oleh tim peneliti pada penelitian sebelumnya (Wedashwara et al., 2020).

Tabel 4. Evaluasi Ketersediaan Tenaga Surya

\begin{tabular}{|c|c|c|c|c|c|c|c|c|c|}
\hline \multirow[b]{2}{*}{ Waktu } & \multirow{2}{*}{$\begin{array}{c}\text { Cahaya } \\
\text { (lux) }\end{array}$} & \multirow{2}{*}{$\underset{{ }^{\circ} \mathrm{C}}{\text { Suhu }}$} & \multicolumn{2}{|c|}{ Solar Panel } & \multicolumn{2}{|c|}{ Baterai } & \multirow{2}{*}{$\begin{array}{c}\text { Through- } \\
\text { put } \\
(\%)\end{array}$} & \multirow{2}{*}{$\begin{array}{c}\text { PDR } \\
(\%)\end{array}$} & \multirow{2}{*}{$\begin{array}{c}\text { Delay } \\
\text { (s) }\end{array}$} \\
\hline & & & $\begin{array}{c}\text { Arus } \\
\text { (A) }\end{array}$ & $\begin{array}{c}\text { Tegangan } \\
\text { (V) }\end{array}$ & $\begin{array}{c}\text { Arus } \\
\text { (A) }\end{array}$ & $\begin{array}{c}\text { Tegangan } \\
\text { (V) }\end{array}$ & & & \\
\hline 08-11 & & 29,43 & 0,531 & 4 & 0,223 & & & & 0,001 \\
\hline $11-16$ & 44256 & 32,92 & 0,362 & 5,182 & 0,214 & 3,612 & 99,334 & 99,629 & 0,001 \\
\hline $16-18$ & 14897 & 31,31 & 0,2 & 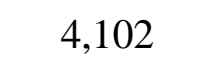 & 37 & & 99 & 8 & 0,002 \\
\hline $18-20$ & 5176 & 29,61 & 0,102 & 0,102 & 0,245 & 3,102 & 99,887 & 98,225 & 0,011 \\
\hline $20-05$ & 91 & 28,34 & 0 & 0 & & & & & 0,027 \\
\hline 05-08 & 12132 & 29,34 & 0,334 & 4,347 & 0,235 & 2,882 & 99,887 & 95,397 & 0,013 \\
\hline $08-11$ & 14623 & 29,52 & 0,64 & 4,123 & 0,262 & 3,135 & 99,623 & 97,682 & 0,011 \\
\hline \multirow[t]{2}{*}{$11-16$} & 44934 & 32,21 & 0,425 & 5,424 & 0,222 & 3,321 & 99,221 & 99,323 & 0,012 \\
\hline & 17945 & 29,85 & 0,350 & 3,473 & 0,235 & 3,078 & 99,653 & 96,656 & 0,016 \\
\hline
\end{tabular}

Tabel 4 menunjukkan intensitas cahaya dan suhu tertinggi pada jam 11-16 dan menghasilkan energi yang maksimal dalam charging baterai. Konsumsi listrik oleh komunikasi data nRF24L01 termasuk stabil dengan rata-rata 0.350 Ampere untuk arus dan 3,473 volt untuk tegangan. throughput, PDR dan delay secara keseluruhan tidak terlalu banyak mengalami selisih antara kondisi optimal yaitu siang hari dan tidak optimal yaitu malam hari. Malam hari yaitu 20-05 dan 05-08 memiliki QoS terendah yaitu paling tampak pada penurunan PDR 94,221\% dan delay 0,027s. Hal ini dikarena karena penurunan tegangan 
pada baterai yaitu 0,221A dan 2,976v. Secara keseluruhan rata-rata QoS cukup tinggi throughput adalah 99,653\%, PDR 96,656\% dan delay 0,016s.

Perbandingan ketersediaan energi dengan penelitian sebelumnya (Wedashwara et al., 2020) yang menggunakan komunikasi data wifi menunjukkan hasil yang lebih baik. Untuk perbandingan energi yang dihasilkan melalui solar panel ada faktor cuaca yaitu pada penelitian ini intensitas cahaya 17945 lux lebih tinggi dibanding 16023 lux pada penelitian sebelumnya. Suhu udara juga tergolong lebih rendah yaitu 29,85 celcius dibanding 31,45 celcius pada penelitian sebelumnya sehingga lebih menguntungkan bagi penelitian ini. Sehingga rata-rata energinya dihasilkan lebih baik dari segi arus yaitu 0,350A dibanding 0,312 A dan tegangan 3,473 V dibanding $2,921 \mathrm{~V}$ pada penelitian sebelumnya.

Untuk penggunaan beraterai juga penelitian ini menunjukkan hasil yang jauh lebih baik karena memang beban konsumsi listrik jauh lebih rendah. Penelitian ini menghasilkan ratarata konsumsi arus hanya $0,235 \mathrm{~A}$ dibanding $0,987 \mathrm{~A}$ pada penelitian sebelumnya. Untuk tegangan tidak jauh berbeda yaitu 3,078V dan 2,987V karena menggunakan modul TP4056 untuk stabilitas tegangan bagi beban. Untuk melakukan perbandingan konsumsi listrik, penghasilan tenaga surya dan QoS yang setara perlu dilakukan pengujian dengan komunikasi data lain seperti Wifi, LoRa dan Bluetooth yang menggunakan tenaga surya. Beban konsumsi listrik juga harus disamakan sehingga perbandingan bisa diukur secara setara.

\section{SIMPULAN}

Penelitian ini telah merancang bangun prototype WSN berbasis nRF24L01 dan SIM8001 bertenaga surya untuk Implementasi IoT secara outdoor yang sepenuhnya portable dapat melakukan monitoring QoS sekaligus ketersediaan tenaga surya. Hasil evaluasi menunjukkan untuk komunikasi data searah topology star memiliki hasil yang lebih baik dengan PDR 99,099\%, throughput 99,393\% dan delay 0,0095s. Sedangkan topologi bus menghasilkan perbedaan tipis PDR 98,766\%, throughput 98,461\% dan delay 0,017s. Evaluasi ketersediaan energi menunjukkan waktu siang hari dengan rata-rata tegangan 3,703v dan malam hari 2,976v tidak menghasilkan perbedaan yang signifikan. Siang hari menghasilkan PDR 99,301\%, throughput 99,653\% dan delay 0,001s, sedangkan malam hari PDR 94,221\%, throughput $99,881 \%$ dan delay $0,027 \mathrm{~s}$. Penelitian juga menghasilkan rata-rata tenaga surya dan konsumsi betarai yang lebih baik dari penelitian sebelumnya yang menggunakan wifi.

\section{REFERENSI}

Abayomi-Alli, O., Odusami, M., Ojinaka, D., Shobayo, O., Misra, S., Damasevicius, R., \& Maskeliunas, R. (2018). Smart-Solar Irrigation System (SMIS) for Sustainable Agriculture. International Conference on Applied Informatics, 198-212. Springer, Cham.

Akbar, T., \& Gunawan, I. (2020). Prototype Sistem Monitoring Infus Berbasis IoT (Internet Of Things). Edumatic: Jurnal Pendidikan Informatika, 4(2), 155-163. https://doi.org/10.29408/edumatic.v4i2.2686

Aponte-Luis, J., Gómez-Galán, J. A., Gómez-Bravo, F., Sánchez-Raya, M., Alcina-Espigado, J., \& Teixido-Rovira, P. M. (2018). An efficient wireless sensor network for industrial monitoring and control. Sensors, 18(1), 1-15. https://doi.org/10.3390/s18010182

Bassoli, M., Bianchi, V., De Munari, I., \& Ciampolini, P. (2017). An IoT approach for an AAL Wi-Fi-based monitoring system. IEEE Transactions on Instrumentation and Measurement, 66(12), 3200-3209. 10.1109/TIM.2017.2753458

Gao, J., Wang, X., Shen, R., \& Xu, Y. (2021). User Clustering and Power Allocation for mmWave MIMO-NOMA with IoT devices. Wireless Communications and Networking Conference (WCNC), 1-6. Nanjing, China: IEEE. 
Iwasaki, S., Tazawa, S., Oshima, T., \& Ishizawa, H. (2014). Selection of Wavelength Range on Non-invasive Blood Glucose Measurement Using Near-infrared Spectroscopy. 3-6.

Keliwar, S. (2020). A Secondary Study Examining the Effectiveness of Network Topologies: The Case of Ring, Bus, and Star Topologies. International Journal of Communication and Computer Technologies, 8(2), 5-7.

Khan, A., Aziz, S., Bashir, M., \& Khan, M. U. (2020). IoT and wireless sensor network based autonomous farming robot. International Conference on Emerging Trends in Smart Technologies (ICETST), 1-5. Karachi, Pakistan: IEEE. 10.1109/ICETST49965.2020.9080736

Lauridsen, M., Nguyen, H., Vejlgaard, B., Kovács, I. Z., Mogensen, P., \& Sorensen, M. (2017). Coverage comparison of GPRS, NB-IoT, LoRa, and SigFox in a $7800 \mathrm{~km}^{2}$ area. 2017 IEEE 85th Vehicular Technology Conference (VTC Spring), 1-5. Sydney, NSW, Australia: IEEE.

Lee, H.-C., \& Ke, K.-H. (2018). Monitoring of large-area IoT sensors using a LoRa wireless mesh network system: Design and evaluation. IEEE Transactions on Instrumentation and Measurement, 67(9), 2177-2187.

Lee, J., Kim, K., Park, S., Byun, H., Shim, K., \& An, B. (2017). IoT based mobile smart monitoring system for solar power generation. Journal of the Institute of Electronics and Information Engineers, 54(8), 55-64.

Li, S., Da Xu, L., \& Zhao, S. (2018). 5G Internet of Things: A survey. Journal of Industrial Information Integration, 10, 1-9.

Talukder, S., Sakib, M. I. I., Talukder, Z. R., Das, U., Saha, A., \& Bayev, N. S. N. (2017). Usensewer: Ultrasonic sensor and gsm-arduino based automated sewerage management. International Conference on Current Trends in Computer, Electrical, Electronics and Communication (CTCEEC), 12-17. Mysore, India: IEEE.

Vaidya, D., Mukherjee, S., Zagrodnik, M. A., \& Wang, P. (2017). A review of communication protocols and topologies for power converters. IECON 2017-43rd Annual Conference of the IEEE Industrial Electronics Society, 2233-2238. Beijing, China: IEEE.

Vidyasagaran, S., Devi, S. R., Varma, A., Rajesh, A., \& Charan, H. (2017). A low cost IoT based crowd management system for public transport. International Conference on Inventive Computing and Informatics (ICICI), 222-225. Coimbatore, India: IEEE.

Wang, J., Gao, Y., Liu, W., Sangaiah, A. K., \& Kim, H.-J. (2019). An improved routing schema with special clustering using PSO algorithm for heterogeneous wireless sensor network. Sensors, 19(3), 1-17. https://doi.org/10.3390/s19030671

Wedashwara, W., Arimbawa, I. W. A., Jatmika, A. H., Zubaidi, A., \& Mulyana, T. (2020). IoT based Smart Small Scale Solar Energy Planning using Evolutionary Fuzzy Association Rule Mining. International Conference on Advancement in Data Science, ELearning and Information Systems (ICADEIS), 1-6. Indonesia: IEEE

Wedashwara, W., Mabu, S., Obayashi, M., \& Kuremoto, T. (2015). Evolutionary Rule Based Clustering for Making Fuzzy Object Oriented Database Models. Advanced Applied Informatics (IIAI-AAI), The 4th International Congress On, 517-522. Indonesia: IEEE

Yoon, I., Kim, H., \& Noh, D. K. (2017). Adaptive data aggregation and compression to improve energy utilization in solar-powered wireless sensor networks. Sensors, 17(6), 116. https://doi.org/10.3390/s17061226 